\title{
Study of Different Rates of Application of Pendimethalin and Acetochlor on Weed Infestation and Grain Yield of Fababean
}

\author{
Hajjaj B., \\ Tantaoui H., \\ El Oualkadi A.,
}

National Institute of Agronomic Research, Tangier, Morocco

Doi:10.19044/esj.2019.v15n36p246 URL:http://dx.doi.org/10.19044/esj.2019.v15n36p246

\begin{abstract}
A fababean weed control trial was conducted during the 2016-2017 growing season. The aim of this study is to investigate the effect of two preemergence herbicides Pendimethalin and Acetochlor on weed infestation in a fababean crop. Dominant weed botanical families in the experimental site belong to Asteraceae and Poaceae. Results showed that the improvement of fababean grain yield depends on the weed control efficacy. Treatment with Pendimethalin at $1228 \mathrm{~g} / \mathrm{ha}$ widely decrease fababean weed infestations recording $91.7 \%$ and 90.56 respectively on visual efficacy rating and weed biomass reduction. Acetochlor at $1050 \mathrm{~g} / \mathrm{ha}$ recorded the lowest efficacies $53.3 \%$ and $62.1 \%$ respectively on visual efficacy rating and weed biomass reduction. Plots treated with Pendimethalin at $1228 \mathrm{~g} / \mathrm{ha}$ recorded the best yields with an average of 3.32 tons / ha.
\end{abstract}

Keywords: Weed Infestation, Fababean, Pendimethalin, Acetochlor, Efficacy, Biomass, Morocco

\section{Introduction}

Food legumes are second in crop rotation in Morocco after cereals (Elalaoui, 2000). Food legumes cover an area of 201000 hectares (MAPMDREF, 2017). Fababean is the most important food legume, it covers an area of 82800 ha with a production of 26560 tons (MAPMDREF, 2017). These crops play several agronomic, nutritional and economic roles (Daoui et al., 2015), as they contribute to the improvement of the soil structure and enrichment through the symbiotic fixation of atmospheric nitrogen and they improve the quality of the human and animal food ration because of their high protein content. In Morocco, fababean production is concentrated in two main areas; Sais region and the Pre-Rif region (Ouazzane, Chefchaouen, Taounate, 
Taza) and in the central western region of the country (Chaouia, Abda and Dokkala) (Fatemi et al., 2005). Weeds are a serious constraint to fababean productivity in Morocco especially orobanche and dicotyledonous weeds (Zemrag, 1994; Zemrag, 1997; Zemrag, 1999; Hajjaj 2010; Baye, 2012; Guennouni, 2012; Bouhache and Benmansour, 2014 ; Dahan et al., 2016; Hajjaj et al.,2016, Tanji A. 2001; Tanji, 2013; Tanji A. 2018). Indeed, weeds compete with crops using water, nutrients and lights (Spitters and Van Den Bergh, 1982). Dicotyledonous weeds are a serious problem in fababean in Morocco because of the scarcity of registered broadleaf herbicides on this crop (Ezzahiri et al., 2014). Surveys carried out in different regions of Morocco have shown that dominant weed botanical families found in food legumes are Asteraceae, Fabaceae, Apiaceae, Brassicaceae and Poaceae (Baye, 2015). Pendimethalin in pre-emergence is recommended to control dicotyledonous weeds and could be followed by a post-emergence herbicide which control grass weeds (Fluazifop butyl, Haloxyfop and Cycloxydime) (Baye, 2015). Pendimethalin and Acetochlor are two pre-emergence herbicides that may reduce weed infestation in fababean depending on rates of application and the nature of weed flora infestation. No studies have been conducted on weed efficacy of these herbicides in the Ouazzane region. This study aims to evaluate different doses of Pendimethalin and Acetochlor on weed infestation in fababean in the Ouazzane region, Morocco.

\section{Material And Methods}

A trial of weed control of fababean was conducted in Ouazzane region during 2016-2017 growing season. Two pre-emergence herbicides were tested (Table 1). Treatments were carried out using a Backpack herbicide sprayer with nozzle delivering a 3 bar jet. The spray volume per hectare is 2001. The experimental design was a random block with tree repetitions. The distance between the blocks is 2 meters and the distance between plots was 1 meter. Each block contained 4 elementary plots, 3 plots of which are treated with the herbicides tested (Table 1) and one untreated control plot. The size of the elementary plots was $2 \mathrm{~m}$ x $5 \mathrm{~m}\left(10 \mathrm{~m}^{2}\right)$. Pre-emergence herbicides were applied three days after fababean sowing on November 07, 2016. Observations were made on January 11, 2017. Observations concerned visual rating of efficacy on a scale ranging from zero to $100 \%$ (where $0 \%$ is ineffective while $100 \%$ is a total destruction of weeds) and percentage of dry biomass reduction. Weed dry biomass reduction percentage $=$ [weed dry biomass weight in control plots - weed dry biomass weight in treated plots] x 100 / [weed dry biomass weight in control plots]. Calculation of dry weed biomass were made by collecting weeds in each plot using a quadrat of $1 \mathrm{~m}$ x $1 \mathrm{~m}$. Samples were dried in a drying oven at $75^{\circ} \mathrm{C}$ for 48 hours. Then, dry plant material in each plot was weighed with a precision balance. Statistical analyzes were performed with SPSS 
software version 21.0 using the analysis of variance (ANOVA). The difference among treatment means was compared by Tukey's test at $\mathrm{p} \leq 0.05$.

Table 1: Applied herbicides in experimental site

\begin{tabular}{ccc}
\hline $\begin{array}{c}\text { Herbicide } \\
\text { treatments }\end{array}$ & $\begin{array}{c}\text { Herbicide active } \\
\text { ingredient }\end{array}$ & $\begin{array}{c}\text { rate of application } \\
\text { (g/hectare) }\end{array}$ \\
\hline Treatment 1 & Pendimethalin & 614 \\
Treatment 2 & Pendimethalin & 1228 \\
Treatment 3 & Acetochlor & 1050 \\
\hline
\end{tabular}

\section{Results And Discussion}

\section{Weed flora}

A floristic survey at the trial site revealed 18 species belonging to 11 botanical families, of which $88.9 \%$ are annuals. The dicotyledons contribute $66.6 \%$ and the monocotyledons $33.3 \%$. Dominant weed botanical families in the experimental area are Asteraceae and Poaceae as they contribute more than half of the species diversity in the experimental site (Table 2). Others studies reported that Asteraceae and Poaceae contribute in total by $26.7 \%$ in Chaouia region (Taleb and Maillet, 1994). This shows the importance of weed infestation of these two botanical families in Ouazzane region.

\section{Effect on visual efficacy rating}

Statistical analysis revealed significant differences in the efficacy of treatments on fababean weeds. Pendimethalin at $1228 \mathrm{~g} / \mathrm{ha}$ gave the best efficacy recording $91.7 \%$ of weed control (Table 3 ). Thus, the efficacy of Pendimethalin at $1228 \mathrm{~g} / \mathrm{ha}$ was different from all other treatments. Acetochlor at $1050 \mathrm{~g} / \mathrm{ha}$ and Pendimethalin at $614 \mathrm{~g} / \mathrm{ha}$ recorded lower efficacies with respective efficacies of respectively $53.3 \%$ and $63.3 \%$. Others authors reported that Pendimethalin at $1050 \mathrm{~g} / \mathrm{ha}$ recorded $93.3 \%$ of weed control in Meknes region of Morocco (Bouhache and Benmansour, 2014), this result confirms our observation in Ouazzane region. Furthermore, other study in Doukkala region (Morocco) tested the association of Pendimethalin at 600 $\mathrm{g} / \mathrm{ha}$ with Acetochlor $840 \mathrm{~g} / \mathrm{ha}$. However, the observed efficacy of that treatment did not exceed $70 \%$ weed control (Tanji, 2012).

Table 2: Weed flora in experimental site

\begin{tabular}{lll}
\hline \multicolumn{1}{c}{ Scientific Names } & Botanical families & Life cycle \\
\hline Anacyclus maroccanus Ball & Asteraceae & Annual \\
Anagallis arvensis L. & Primulaceae & Annual \\
Arisarum vulgare Targ.-Tozz. & Araceae & Perennial \\
Avena sterilis L. & Poaceae & Annual \\
Bromus rigidus Roth & Poaceae & Annual \\
Chrysanthemum coronarium L. & Asteraceae & Annual \\
Chrysanthemum segetum L. & Asteraceae & Annual
\end{tabular}




\begin{tabular}{lll} 
Convolvulus arvensis $\mathrm{L}$. & Convolvulaceae & Perennial \\
Euphorbia helioscopia L. & Euphorbiaceae & Annual \\
Gallium tricornutum Dandy & Rubiaceae & Annual \\
Lolium rigidum Gaudin & Poaceae & Annual \\
Malva parviflora L. & Malvaceae & Annual \\
Phalaris brachystachys Link & Poaceae & Annual \\
Phalaris paradoxa L & Poaceae & Annual \\
Plantago afra L. & Plantaginaceae & Annual \\
Ridolfia segetum Moris & Apiaceae & Annual \\
Sonchus oleraceus L. & Asteraceae & Annual \\
Vicia spp. & Fabaceae & Annual \\
\hline
\end{tabular}

Table 3: Effect on visual efficacy rating at $60 \mathrm{DAT}^{*}$

\begin{tabular}{cc}
\hline Treatments & Efficacy $(\%)$ \\
\hline Pendimethalin at $614 \mathrm{~g} / \mathrm{ha}$ & $63.3 \mathrm{a}$ \\
Pendimethalin at $1228 \mathrm{~g} / \mathrm{ha}$ & $91.7 \mathrm{~b}$ \\
Acetochlor at $1050 \mathrm{~g} / \mathrm{ha}$ & $53.3 \mathrm{a}$ \\
\hline$P \alpha=0,05$ & $<0,00$ \\
\hline
\end{tabular}

Significant differences within the same column and means followed by the same letter do not differ at $P \alpha \leq 0.05$ according to Tukey's test.

* DAT: days after treatment

\section{Effect on weed dry biomass reduction}

Statistical analysis revealed significant differences between treatments (table 4). Plots treated with Pendimethalin at $1228 \mathrm{~g} / \mathrm{ha}$ showed the best efficacy recording $90.56 \%$ of weed dry biomass reduction compared to weed dry biomass in the control plots. Plots treated by Pendimethalin at $614 \mathrm{~g} / \mathrm{ha}$ and Acetochlor at $1050 \mathrm{~g} / \mathrm{ha}$ showed medium weed dry biomass reduction recording only $74.20 \%$ and $62.10 \%$ respectively. Compared to another study conducted in Tadla region of Morocco in 2010 (Baye, 2012), Pendimethalin at $1200 \mathrm{~g} /$ ha showed only $70 \%$ of weed dry biomass reduction in a fababean weeding trial. This low efficacy can be explained by the nature of weed flora species since weed infestations differ in agricultural regions of Morocco. Therefore, it is important to adapt rates of application of Pendimethalin in different region according to weed infestation. 
Table 4: Effect on weed dry biomass reduction

\begin{tabular}{cc}
\hline Treatment & Weed dry biomass reduction (\%) \\
\hline Pendimethalin at $614 \mathrm{~g} / \mathrm{ha}$ & $74.20 \mathrm{a}$ \\
Pendimethalin at $1228 \mathrm{~g} / \mathrm{ha}$ & $90.56 \mathrm{~b}$ \\
Acetochlor at $1050 \mathrm{~g} / \mathrm{ha}$ & $62.10 \mathrm{a}$ \\
\hline$P \alpha=0.05$ & 0.001 \\
\hline
\end{tabular}

Significant differences within the same column and means followed by the same letter do not differ at $P \alpha \leq 0.05$ according to Tukey's test.

\section{Effect on grain yield}

Table 5: Effect of treatments on total yield of fababean (tons/ha)

\begin{tabular}{lc}
\hline \multicolumn{1}{c}{ Treatment } & Grain yield (tons/ha) \\
\hline Pendimethalin at $614 \mathrm{~g} / \mathrm{ha}$ & $1.77 \mathrm{~b}$ \\
Pendimethalin at $1228 \mathrm{~g} / \mathrm{ha}$ & $3.32 \mathrm{a}$ \\
Acetochlor at $1050 \mathrm{~g} / \mathrm{ha}$ & $1.52 \mathrm{bc}$ \\
control & $1.24 \mathrm{c}$ \\
\hline$P \alpha=0,05$ & $<0,00$ \\
\hline
\end{tabular}

Significant differences within the same column and means followed by the same letter do not differ at $P \alpha \leq 0.05$ according to Tukey's test.

Statistical analysis revealed significant differences between grain yields of treated plots (Table 5). Results show grain yield superiority of plot treated with Pendimethalin at $1228 \mathrm{~g} /$ ha recording 3.32 tons / ha. The lowest yield is recorded by the control with 1.24 tons/ha. Grain yields of Acetochlor at $1050 \mathrm{~g} / \mathrm{ha}$ and Pendimethalin at $614 \mathrm{~g} / \mathrm{ha}$ treatments are also low, recording respectively 1.52 and 1.77 tons/ha. Despite the fact that grain yield recorded by Pendimethalin at $614 \mathrm{~g} / \mathrm{ha}$ is greater than recorded untreated control grain yield, nonetheless grain yield of Pendimethalin at $614 \mathrm{~g} / \mathrm{ha}$ remains low compared to the potential of the crop. In addition, it is important to mention that the calculation of correlation coefficient between treatment efficacies and recorded fababean grain yield showed a coefficient of 0.891: highly significant. This means that grain yields are higher as the weed control efficacies of the treatments increase.

\section{Conclusion}

This study has shown that the improvement of fababean grain yields is closely related to good weed control. Indeed, Pendimethalin at $1228 \mathrm{~g} / \mathrm{ha}$ gave the best fababean grain yield recording $3.32 \mathrm{qx} / \mathrm{ha}$ and allows to reduce weed infestation by recording $91.70 \%$ and $90.56 \%$ respectively on visual efficacy rating and weed biomass reduction. Pendimethalin at $1228 \mathrm{~g} / \mathrm{ha}$ can be recommended to farmers in Ouazzane region. This study should be repeated 
at different sites and with different soils to evaluate Pendimethalin and Acetochlor effects on different weed infestation situations.

\section{References:}

1. Baye Y. (2012). Possibilités de désherbage chimique des légumineuses alimentaires en irrigué. Proc. 8ème Congrès de l'AMPP, Rabat. Pages : 445-454.

2. Baye Y. (2015). Mauvaises herbes des légumineuses alimentaires : Espèces rencontrées, impact sur le rendement et moyens de lutte. Guide pratique pour la protection phytosanitaire des céréales et des légumineuses alimentaires. INRA-Maroc éditions 2015. Pages : 54-56.

3. Bouhache M, and Benmansour S (2014). Possibilités de désherbage chimique de la féverole (Vicia faba var. minor) conduite en irrigué et en bour. Revue Marocaine de Protection des Plantes 6 : 51-62.

4. Dahan R., Kradi C., Mentag R., Bamouh A., El Asri M., Mouaaid A., Tirazi R. et Haddasakr E.M. (2016). Guide pratique pour le conseil agricole : lentille, pois chiche et fève. INRA Edition 2016.

5. Daoui K., Karrou M., Mrabet R., Fatemi Z., and Oufdou K. (2015). Fababean Fertilization in Morocco. Better Crops/Vol. 99 (2015, No. 4). Pages: 12-13.

6. Elalaoui A. C. (2000). Mécanisation de la culture des Légumineuses alimentaires au Maroc. Bulletin de Transfert de technologie en agriculture $\mathrm{N}^{\circ} 64$.

7. Ezzahiri B., Bouhache M. and Mihi M. (2017). Index Phytosanitaire Maroc, 304p.

8. Fatemi Z. E. A., Sakr B. and Abbad A. F. (2005). Amélioration génétique de la fève et féverole. La création variétale à l'INRA méthodologie, acquis et perspectives. INRA éditions 2005. 171 p.

9. Guennouni A. (2012). Orobanche, principal ennemi des légumineuses au Maroc. Agriculture du Maghreb N57. Pages : 93-95.

10. Hajjaj B. (2010). Diagnostic de la situation du désherbage chimique des céréales et légumineuses dans la région de Sidi El Aidi (Chaouia) et Jemaa shaim (Abda). Proc. 7ème congés de l'Association Marocaine de Protection des Plantes. Pages : 357 364.

11. Hajjaj B., Bouhache M, Mrabet R., Taleb A. and Douaik A. (2016). Efficacité de quelques séquences d'herbicides contre les mauvaises herbes du pois chiche et de la féverole conduits en semis direct. Rev. Mar. Sci. Agron. Vét. (2016) 4 (3). Pages : 37-47. 
12. MAPMDREF (2017). Ministère de l'Agriculture, de la Pêche Maritime, du Développement Rural et des Eaux et Forêts, MAROC. Division des statistiques.

13. Spitters C.J.T. and Van Den Bergh J.P. (1982). Competition between crop and weeds: A system approach. In Biology and ecology of weeds. W. Holzner and N. Numata (eds.) 1982. Dr W. Junk Publishers, The Hague. ISBN 9061936829.

14. Taleb A. and Maillet J. (1994). Mauvaises herbes des céréales de la Chaouia (Maroc), Aspect floristique. Weed Research, 1994. Volume 34. Pages : 345-352.

15. Tanji A (2012). Contribution au désherbage chimique des légumineuses alimentaires. Proc.8ème Congrès de l'AMPP, Rabat. Pages : 409-419.

16. Tanji A (2013). Légumineuses alimentaires, gestion intégrée des adventices. Agriculture de Maghreb 71. Pages : 60-61.

17. Tanji A. (2001) Adventices de la fève non irriguée dans la province de Settat. Revue Al Awamia $N^{\circ} 103$. Pages : 71-81.

18. Tanji A. (2018) Fève et féverole, quoi de neuf pour le désherbage. Agriculture de Maghreb $\mathrm{N}^{\circ} 114$. Pages : 70-73.

19. Zemrag A. (1994). Lutte chimique contre les adventices dans une culture de fève. Compte rendu des journées des légumineuses alimentaires. Mehdia du 05 au 07 Octobre. Pages : 253-256.

20. Zemrag A. (1997). Les acquis de recherche en matière de désherbage: cas des légumineuses alimentaires. Association marocaine de Malherbologie, Journée nationale sur la problématique du désherbage des grandes cultures, Meknès, 26 février 1997. Pages : 15-28.

21. Zemrag A. (1999). L'orobanche, monographie et gestion dans la culture des légumineuses alimentaires. Bulletin de transfert de technologie en agriculture Maroc $\mathrm{N}^{\circ} 66$. 